\title{
ANALISIS PENGARUH GAYA HIDUP, KUALITAS PRODUK TERHADAP KEPUTUSAN PEMBELIAN DENGAN CITRA MEREK SEBAGAI VARIABEL INTERVENING \\ (Studi Kasus J-Co Suzuya Mall Rantauprapat)
}

\author{
Eva Fitria \\ Dosen Tetap Sekolah Tinggi Ilmu Ekonomi (STIE) Labuhan Batu
}

\begin{abstract}
J-Co merupakan salah satu perusahaan Coffeehouse yang terkenal dengan menyajikan warna yang berbeda dibandingkan café tempat minum kopi pada umumnya. J-Co tidak hanya dikunjungi untuk membeli makanan atau minuman tetapi juga dijadikan sebagai tempat pertemuan berbagai komunitas ataupun tempat pertemuan bisnis yang dapat memberikan kenyamanan pada pelanggan.
\end{abstract}

Penelitian ini bertujuan untuk mengetahui dan menganalisis pengaruh gaya hidup dan kualitas produk terhadap keputusan pembelian dengan citra merek sebagai variabel intervening. Penelitian ini merupakan penelitian statistik deskriptif dan sifat penelitian merupakan deskriptif explanator. Populasi dalam penelitian ini adalah pelanggan yang berkunjung ke J-Co Suzuya Mall Rantauprapat. Metode analisis data yang digunakan adalah Path Analysis dengan menggunakan software SPSS 22. Hasil substruktur pertama menunjukkan gaya hidup, kualitas produk secara simultan berpengaruh positif dan signifikan terhadap citra merek dengan koefisien determinasi $27,2 \%$,

Secara parsial Gaya hidup dan kualitas produk berpengaruh terhadap citra merek. Hasil penelitian substruktur kedua menunjukkan gaya hidup, kualitas produk dan citra merek secara simultan berpengaruh signifikan terhadap keputusan pembelian dengan koefisien determinasi Adjusted $\mathrm{R}$ Square $\left(\mathrm{R}^{2}\right)$ sebesar 0,251 atau $25,1 \%$. Secara parsial gaya hidup, kualitas produk dan citra merek berpengaruh signifikan terhadap keputusa pembelian. Citra merek merupakan variabel intervening pada kualitas produk terhadap keputusan pembelian

Kata Kunci : gaya hidup, kualitas produk, citra merek, keputusan pembelian 


\section{A. PENDAHULUAN}

\subsection{Latarbelakang Masalah}

Bisnis merupakan suatu kegiatan atau aktivitas yang dilakukan oleh suatu perusahaan untuk mencari keuntungan. Pada dasarnya sebuah perusahaan atau organisasi bisnis mempunyai tujuan untuk dapat bertahan hidup, mendapatkan laba dan berkembang. Hal tersebut tentunya dapat dicapai dengan menggunakan strategi yang mampu bersaing dengan perusahaan lain. Saat ini perkembangan usaha bisnis semakin mengalami peningkatan terutama yang sedang berkembang adalah bisnis kuliner, khususnya bisnis yang banyak menawarkan aneka cita rasa kopi (Napitupulu, 2018)

Perkembangan warung kopi atau yang modern disebut dengan Coffe Shop belakangan ini semakin pesat. Coffe Shop saat ini bukan hanya sekedar tempat makan dan minum saja tetapi juga dijadikan sebagai tempat pertemuan berbagai komunitas ataupun tempat pertemuan bisnis yang dapat memberikan kenyamanan pada pelanggan. Ditambah lagi dengan fasilitas yang lengkap memberikan nilai tambah Coffe Shop untuk dapat menarik minat pelanggan, seperti layanan wifi yang sekarang banyak orang butuhkan mulai dari anak remaja sampai dewasa.

Maraknya kemunculan coffee shop saat ini tidak terlepas dari pengaruh gaya hidup kota besar yang menyuguhkan banyak kesenangan bagi para pencarian hiburan dan menjadi tempat "nongkrong" favorit bagi kalangan eksekutif muda dan kini meluas di kalangan remaja. (Herlyana, 2012)

Maka tidak heran apabila hobi minum kopi sekarang sudah menjadi life style tersendiri bagi semua kalangan mulai usia remaja sampai dewasa. Selain itu gaya hidup konsumen yang cenderung konsumtif dan menginginkan kepraktisan, juga menyebabkan berbagai jenis kedai kopi baik berskala kecil maupun bertaraf global mulai bermunculan (Sudarmono dan Kholidin,2015)

J.CO sebagai salah satu kedai kopi bermerek telah membuka gerai cabang di Rantauprat. J-Co diRantauprapat mengalami perkembangan dikarenakan hanya satu-satunya Coffeshop yang ada diRantauprapat menawarkan fasilitas yang berbeda dengan konsep modern. Akan tetapi J-Co harus tetap mampu bersaing dan bertahan dengan keberhasilannya saat ini, karena diRantauprapat juga sudah banyak temapat-temapat nongkrong, ngopi dengan menawarkan konsep yang menarik. Jika dilihat dari data top brand J-Co belum unggul dibanding dengan sesama pemain bisnisnya. Hal tersebut terlihat dari penurunan citra merek yang akan ditampilkan pada Tabel di bawah ini 


\section{Tabel 1 \\ Top Brand Index Cafe Kopi (2012-2014)}

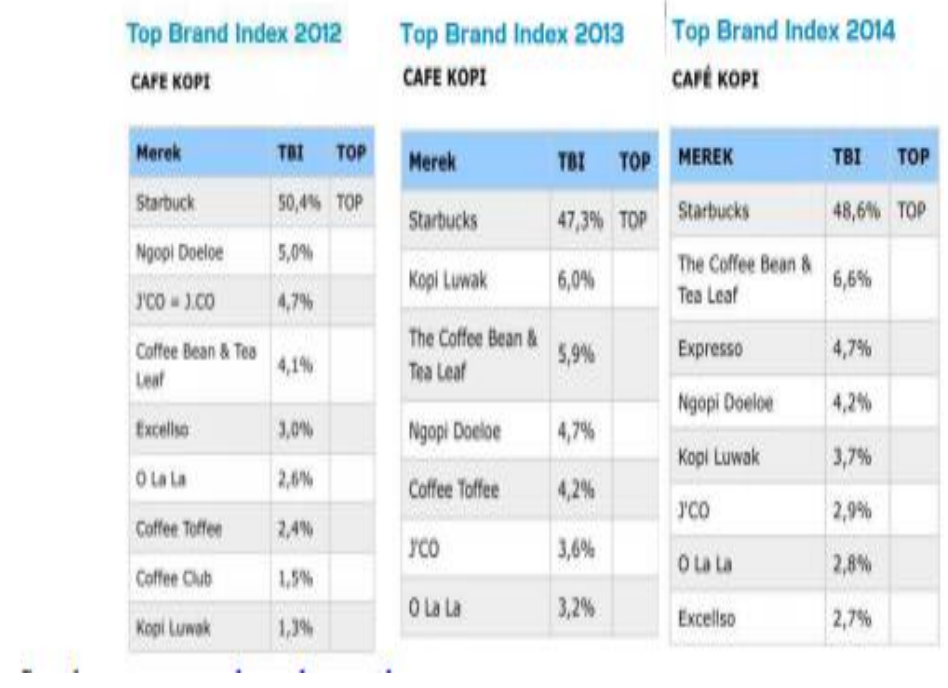

Sumber: : www.topbrand-award.com

Berdasarkan Tabel diatas dari berbagai merek coffee shop yang ada telah menunjukkan adanya peringkat J.CO yang terus menerus mengalami penurunan selama 3 tahun terakhir. Pada tahun 2012 J.CO menempati posisi 3 teratas sebagai brand cafe kopi terbaik di Indonesia dengan nilai index sebesar 4,7\%. Kemudian Brand index J.CO terus menerus mengalami penurunan pada tahun 2013 dan 2014 berturut - turut sebesar 3,6\% dan 2,9\% (sudarmono dan Kholidin, 2015).

Selain Citra Merek, kelas sosial juga menentukan pelanggan untuk membeli suatu produk. Kelas sosial akan mempengaruhi jenis produk, jenis jasa, dan merek yang dikonsumsi konsumen. Konsumen juga sering memiliki persepsi mengenai kaitan antara satu jenis produk atau sebuah merek dengan kelas sosial konsumen.

Kelas sosial merupakan bentuk segmentasi yang hierarkis dan alamiah, aspek hierarkis kelas sosial begitu penting bagi pemasar dan produsen untuk menentukan konsumen mana yang akan dituju dari produk yang telah diciptakan, apa untuk status yang lebih tinggi atau status yang lebih rendah.

Selain citra merek dan kelas sosial, gaya hidup juga mempengaruhi minat beli konsumen. Gaya hidup menurut Kotler (2009) adalah pola hidup seseorang di dunia yang diekspresikan dalam aktivitas, minat, dan opininya. Sedangkan menurut Minor dan Mowen (2000), gaya hidup menunjukkan bagaimana seseorang hidup, bagaimana membelanjakan uangnya, dan bagaimana mengalokasikan waktu.

Semakin banyaknya tempat untuk bersantai dan berkumpul dengan rekanan, membuat perubahan dalam gaya hidup di dalam masyarakat kota Rantauprapat 
khususnya anak muda. Bagi mereka gaya hidup yang modern membuat mereka merasa nyaman dan diakui status sosialnya.

Berdasarkan latar belakang tersebut peneliti tertarik melakukan penelitian dengan judul "Pengaruh Gaya Hidup dan Kualitas Produk Terhadap Keputusan Pembelian Dengan Citra Merek Sebagai Variabel Intervening (Studi Kasus J-Co Suzuya Mall Rantauprapat)

\subsection{Rumusan Masalah}

1. Apakah gaya hidup berpengaruh signifikan terhadap citra merek keputusan pembelian pada J-Co Suzuya Mall Rantauprat

2. Apakah kualitas produk berpengaruh signifikan terhadap citra merek pada J-co Suzuya Mall Rantauprat

3. Apakah gaya hidup berpengaruh signifikan terhadap keputusan pembelian pada Jco Suzuya Mall Rantauprat

4. Apakah kualitas produk berpengaruh keputusan pembelian pada J-co Suzuya Mall Rantauprat

5. Apakah citra merek berpengaruh terhadap keputusan pembelian pada J-co Suzuya Mall Rantauprat

6. Apakah gaya hidup berpengaruh signifikan terhadap keputusan pembelian melalui citra merek pada J-co Suzuya Mall Rantauprat

7. Apakah kualitas produk berpengaruh siginifikan terhadap keputusan pembelian melalui citra merek pada J-co Suzuya Mall Rantauprat

\section{B. TINJAUAN PUSTAKA \\ Brand (Merek)}

Menurut Kotler (2009:375) merek adalah norma, istilah, simbol atau rancangan atau kombinasi dari hal-hal tersebut untuk mengidentifikasi barang atau jasa dari seseorang/ sekelompok penjual untuk membedakannya dari produk pesaing. Merek adalah penggunaan nama, logo trade mark, slogan dan identitas visual lainnya untuk membedakan perusahaan -perusahaan dan individu satu sama lain dalam hal apa yang mereka tawarkan secara konsisten. Sedangkan Keller (2008:3) sesuai dengan American Marketing Association (AMA) menyatakan bahwa merek adalah nama, batasan, tanda, simbol atau desain atau kombinasi dinataranya, untuk menidentifikasi barang dan jassa dari satu penjual atau kelompok penjual dan untuk membedakan mereka dari pesaingnya

\section{Brand Image (Citra Merek)}

Menurut Kotler (2009:145) citra merek adalah suatu pemikiran masyarakat yang menghasilkan persepsi (pandangan atau penilaian pribadi) mereka terhadap suatu perusahaan atau produknya. Identitas yang efektif akan memberi hasil sebagai berikut, yakni : Merek tersebut akan mampu untuk membangun karakter produk dan proporsi nilai. Sedangakan Keller (2008:93) mengungkapkan bahwa citra merek dapat dijelaskan 
sebagai persepsi tentang sebuah merek yang digambarkan sebagi asosiasi merek yang ada dalam ingatan konsumen. Brand association (asosiasi merek) adalah informasi lain yang dihubungkan dengan merek dalam ingatan dan mengandung arti merek bagi konsumen.

\section{Tingkatan dan Komponen Citra Merek}

Menurut Kotler (2010:40) terdapat enam tingkatan arti dari merek, yaitu:

1. Atribut, merek pertama-tama akan meningkatkan orang pada atribut produk tertentu.

2. Manfaat, pelanggan tidak membeli atribut melainkan mereka membeli manfaat dari produknya. Maka dari itu, atribut harus diterjemahkan menjadi manfaat fungsional dan emosional

3. Nilai, merek juga mencerminkan nilai yang dimiliki oleh produsen dari sebuah produk.

4. Budaya, suatu merek mewakili suatu kebudayaan tertentu.

5. Kepribadian, merek dapat memproyeksikan pada suatu kepribadian tertentu

6. Pemakai,suatu merek menyarankan jenis pelanggan yang membeli produk

Aaker (2014:90) mengemukakan bahwa dalam pengelolaan merek, baik membangun merek, menentukan citra merek, serta mempertahankan merek, maka setiap perusahaan perlu mempertimbangkan lima faktor berikut :

1. Mengetahui bahwa merek / brand adalah aset yang bernilai strategis. Brand adalah landasan bagi keberhasilan masa depan dan menciptakan nilai berkelanjutan untuk organisasi. Oleh karena itu proses membangun citra merek (brand-building) merupakan upaya strategis yang berbeda dengan upaya taktis untuk merangsang penjualan.

2. Memiliki visi brand menarik yang memandu dan mengilhami. Suatu visi brand harus mencoba bergerak di luar manfaat-manfaat fungsionalnya untuk menentukan nilainilai secara organisasi : tujuan yang lebih tinggi; kepribadian merek (brand personality); manfaat sosial, emosional dan ekspresi diri. Perusahaan harus menemukan kesempatan untuk menciptakan inovasi yang memiliki potensi dimana banyak orang akan menginginkannya, selain itu juga perlu memosisikan kategori serta sub kategori sembari memosisikan brand.

3. Mewujudkan visi brand

Langkah selanjutnya ialah perlunya menciptakan inisiatif dan program-program brand- Perusahaan perlu mencari tahu apa yang merupakan titik-titik favorit para pelanggan untuk melakukan proses inovasi dan menjalankan program brandbuilding dengan building yang mendukung brand itu sendiri. menjadikan brand sebagai mitra. Brand yang kuat biasanya konsisten dalam hal visi brand dan pengeksekusian brand dari waktu ke waktu.

4. Mempertahankan relevansi.

Dalam langkah ini perusahaan perlu untuk mengenali dan menanggapi berbagai ancaman terhadap relevansi dan mempelajari cara untuk menguatkan brand. 
Sedangkan menurut Schiffman dan Kanuk ( 2008:21) faktor-faktor pembentukan citra merek antara lain:

1. Kualitas mutu berkaitan dengan kualitas produk barang yang ditawarkan oleh produsen dengan merek tertentu,

2. Dapat dipercaya atau diandalkan.

3. Kegunaan atau manfaat yang terkait dengan fungsi dari suatu produk barang yang bisa dimanfaatkan oleh konsumen

4. Pelayanan yang berkaitan dengan tugas produsen dalam melayani konsumennya

5. Resiko berkaitan dengan besar kecilnya akibat atau laba dan rugi yang mungkin dialami oleh konsumen

6. Harga dalam hal ini berkaitan dengan tinggi rendahnya atau banyak sedikitnya jumlah uang yang dikeluarkan konsumen untuk mempengaruhi jangka panjang

7. Citra yang dimiliki oleh merek itu sendiri yaitu berupa pandangan kesepakatan dan informasi yang berkaitan dengan suatu merek dari produk tertentu.

\section{Gaya Hidup}

Kotler (2012: 192), mengemukakan bahwa gaya hidup adalah "pola hidup seseorang di dunia yang diekspresikan dalam aktivitas, minat, dan opininya". Gaya hidup menggambarkan keseluruhan diri seseorang dalam berinteraksi dengan lingkungannya.

Menurut Widiastuti (2009:10), pengertian gaya hidup adalah merupakan perilaku seseorang yang ditunjukkan dalam aktivitas, minat dan opini khususnya yang berkaitan dengan citra diri untuk merefleksikan status sosialnya. Gaya hidup seseorang mempengaruhi perilaku pembelian, yang bisa menentukan banyak keputusan konsumsi perorangan.

\section{Faktor-Faktor yang Mempengaruhi Gaya Hidup}

Menurut Kotler (2012:48), mengemukakan bahwa gaya hidup seseorang dapat dilihat dari perilaku yang dilakukan oleh individu seperti kegiatan-kegiatan untuk mendapatkan atau mempergunakan barang-barang dan jasa, termasuk didalamnya proses pengambilan keputusan pada penentuan kegiatan - kegiatan tersebut.

Lebih lanjut Kotler (2012:48), menyatakan bahwa faktor-faktor yang mempengaruhi gaya hidup seseorang ada 2 faktor yaitu faktor yang berasal dari dalam diri individu (internal) dan faktor yang berasal dari luar (eksternal). Faktor internal yaitu

1. Sikap.

Sikap berarti suatu keadaan jiwa dan keadaan pikir yang dipersiapkan untuk memberikan tanggapan terhadap suatu objek yang diorganisasi melalui pengalaman dan mempengaruhi secara langsung pada perilaku.

2. Pengalaman dan Pengamatan.

Pengalaman dapat mempengaruhi pengamatan sosial dalam tingkah laku, pengalaman dapat diperoleh dari semua tindakannya dimasa lalu dan dapat 
dipelajari, melalui belajar orang akan dapat memperoleh pengalaman. Hasil dari pengalaman sosial akan dapat membentuk pandangan terhadap suatu objek.

3. Kepribadian.

Kepribadian adalah konfigurasi karakteristik individu dan cara berperilaku yang menentukan perbedaan perilaku dari setiap individu

4. Konsep diri.

Faktor lain yang menentukan kepribadian individu adalah konsep diri. Konsep diri sudah menjadi pendekatan yang dikenal amat luas untuk menggambarkan hubungan antara konsep diri konsumen dengan image merek.

5. Motif.

Perilaku individu muncul karena adanya motif kebutuhan untuk merasa aman dan kebutuhan terhadap prestise merupakan beberapa contoh tentang motif.

6. Persepsi

Persepsi adalah proses dimana seseorang memilih, mengatur, dan menginterpretasikan informasi untuk membentuk suatu gambar yang berarti mengenai dunia.

Adapun faktor eksternal dijelaskan sebagai berikut :

1. Kelompok Referensi

Kelompok referensi adalah kelompok yang memberikan pengaruh langsung atau tidak langsung terhadap sikap dan perilaku seseorang.

2. Keluarga

Keluarga memegang peranan terbesar dan terlama dalam pembentukan sikap dan perilaku individu. Hal ini karena pola asuh orang tua akan membentuk kebiasaan anak yang secara tidak langsung mempengaruhi pola hidupnya

3. Kelas Sosial

Kelas sosial adalah sebuah kelompok yang relatif homogen dan bertahan lama dalam sebuah masyarakat, yang tersusun dalam sebuah urutan jenjang, dan para anggota dalam setiap jenjang itu memiliki nilai, minat, dan tingkah laku yang sama.

\section{Keputusan Pembelian}

Menurut Kotler (2005:202), "Keputusan pembelian adalah Suatu tahap dimana konsumen telah memiliki pilihan dan siap untuk melakukan pembelian atau pertukaran antara uang dan janji untuk membayar dengan hak kepemilikan atau penggunaan suatu barang atau jasa.

Menurut Kotler (2005:223), tahapan dalam proses pengambilan keputusan pembelian terdiri dari lima tahap, yaitu

1. Pengenalan Masalah

Proses pembelian dimulai saat pembeli mengenai masalah atau kebutuhan. Kebutuhan tersebut dapat dicetuskan oleh rangsangan internal dan external.

2. Pencarian Informasi

Proses pengambilan keputusan pembeli dimana konsumen tergerak untuk mencari informasi tambahan, konsumen mungkin sekedar meningkatkan perhatian dan mungkin pula mencari informasi secara aktif. 
3. Evaluasi Alternatif

Proses keputusan pembeli dimana konsumen menggunakan informasi yang telah di peroleh untuk mengevaluasi berbagai merek alternatif di dalam sejumlah pilihan

4. Keputusan Pembelian

Proses keputusan dimana konsumen secara aktual melakukan pembelian produk.

5. Prilaku Setelah Pembelian

Tahapan proses keputusan pembelian konsumen melakukan tindakan lebih lanjut setelah pembelian berdasarkan pada kepuasan atau ketidakpuasan mereka

\section{Kerangka Konseptual}

Penelitian ini bertujuan mengetahui pengaruh variabel independen yaitu pengaruh Gaya Hidup, Kulaitas Produk terhadap Keptusan Pembelian dengan Citra Merek Sebagai Variabel Intervening (Studi Kasus di Cofe J-CoSuzuya Mall Rantauprapat)

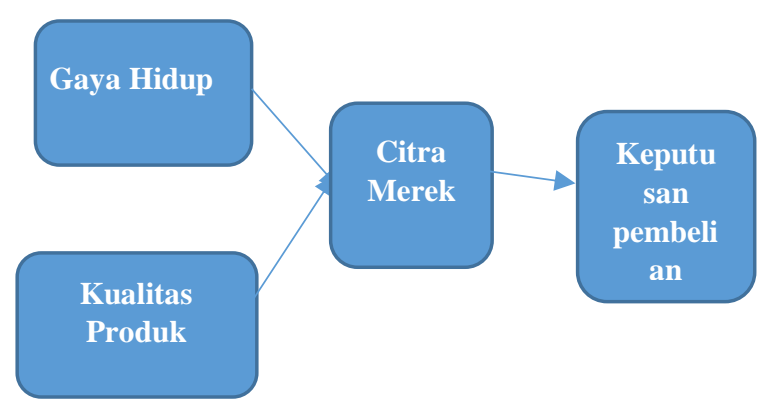

\section{METODE PENELITIAN Jenis dan Sifat Penelitian}

Jenis penelitian ini adalah deskriptif kuantitatif yaitu untuk mengetahui pengaruh variabel Gaya hidup, kualitas produk terhadap keputusan pembelian dengan citra merek sebagai variabel intervening.

\section{Tempat dan Waktu Penelitian}

Penelitian ini dilakukan pada J-Co Suzuya Mall Rantauprapat,JL SM Raja No 126 Aektapa Rantauprapat. 


\section{Populasi dan Sampel}

Populasi dalam penelitian ini adalah Pelanggan J-Co Suzuya Mall Rantauprapat. Populasi dalam penelitian ini sebanyak 1500.

Sampel adalah suatu himpunan bagian dari unit populasi (Kuncoro, 2010:103). Teknik pengambilan sample menggunakan rumus slovin, sehingga sampel yang diperoleh sebanyak 316

\section{Teknik Pengumpulan Data}

Adapun teknik pengumpulan data yang akan dilakukan dalam penelitian ini adalah sebagai berikut:

1. Wawancara (interview) kepada manajemen J-Co Suzuya Mall Rantauprapat memberikan informasi dan keterangan yang sesuai dengan kebutuhan penelitian

2. Daftar pertanyaan (questionare) yang diberikan kepada Pelanggan J-Co Suzuya Mall Rantauprapat

3. Studi dokumentasi yaitu dengan mengumpulkan dan mempelajari data pendukung yang berhubungan dengan masalah penelitian yang diperoleh dari manajemen J-Co Suzuya Mall Rantauprapat.

\section{Jenis dan Sumber Data}

Jenis data yang akan dikumpulkan dalam penelitian ini adalah bersumber dari:

1. Data Primer adalah data yang diperoleh dari jawaban daftar pertanyaan yang diberikan kepada pelanggan sebagai responden pada Coffe Sturbucks Suzuya Mall Rantauprapat.

2. Data sekunder yaitu data yang diperoleh dari studi dokumentasi seperti: Jurnal peraturanperaturan dan dokumen-dokumen lain yang berhubungan dengan penelitian ini.

\section{Teknik Analisis Data}

1. Metode analisis statistik deskriptif

2. Uji hipotesis dengan analisis jalur

Persamaan model matematika dari model jalur adalah sebagai berikut:

a. Persamaan Struktural 1

$\mathrm{Z}=\mathrm{b}_{1} \mathrm{X}_{1}+\mathrm{b}_{2} \mathrm{X}+\mathrm{e} 1$

$\mathrm{Y}=\mathrm{b}_{1} \mathrm{X}_{1}+\mathrm{b}_{2} \mathrm{X}_{2}+\mathrm{b}_{3} \mathrm{Z}+\mathrm{e} 2$

Dimana:

$\mathrm{Y}=$ Keputusan Pembelian

$\mathrm{Z}=$ Citra Merek

$\left(\mathrm{X}_{1}\right) \quad=$ Gaya Hidup

$\left(\mathrm{X}_{2}\right) \quad=$ Kualitas Produk

$\mathrm{e}=$ error terms

\section{HASIL DAN PEMBAHASAN}

\section{Hasil Uji Determinasi $\left(\mathbf{R}^{2}\right)$ Model Persamaan Regresi Pertama}

Untuk melihat besarnya pengaruh pada persamaan struktural 1 yaitu pengaruh gaya hidp, kualitas produk terhadap citra merek 


\section{Hasil Analisis Jalur R-Square Regresi 1}

\section{Model Summary ${ }^{b}$}

\begin{tabular}{|l|c|c|r|r|}
\hline $\begin{array}{l}\text { Mod } \\
\text { el }\end{array}$ & $\mathrm{R}$ & $\begin{array}{c}\mathrm{R} \\
\text { Squar } \\
\mathrm{e}\end{array}$ & $\begin{array}{c}\text { Adjusted } \\
\mathrm{R} \text { Square }\end{array}$ & $\begin{array}{c}\text { Std. Error } \\
\text { of the } \\
\text { Estimate }\end{array}$ \\
\hline 1 &, $557^{\mathrm{a}}$ &, 311 &, 272 &, 47977 \\
\hline
\end{tabular}

\footnotetext{
a. Predictors: (Constant), Kualitas_produk, Gaya_hidup

b. Dependent Variable: Citramerek

Sumber: Output SPSS, datadiolah peneliti, 2018
}

Berdasarkan Tabel nilai nilai koefisien determinasi (Adjusted $R$ Square) adalah sebesar 0,272 atau $27,2 \%$. Koefisien artinya pengaruh gaya hidup dan kualitas produk terhadap citra merek sebesar $27,2 \%$, sedangkan sisanya sebesar $72,8 \%$ dipengaruhi oleh faktor-faktor lain

\section{Pengujian Secara Serempak (Uji F)}

Uji F dilakukan untuk mengetahui apakah semua variabel independen yang dimasukkan ke dalam model memiliki pengaruh secara bersama-sama terhadap variabel dependen. Berikut ini merupakan hasil pengujian hipotesis secara serempak

\section{ANOVA $^{a}$}

Hasil Uji Simultan (Uji F) Model Regresi 1

\section{ANOVA $^{a}$}

\begin{tabular}{|c|c|c|c|c|c|c|}
\hline \multicolumn{2}{|c|}{ Model } & $\begin{array}{l}\text { Sum } \\
\text { of } \\
\text { Squar } \\
\text { es }\end{array}$ & $\mathrm{df}$ & $\begin{array}{l}\text { Mean } \\
\text { Squar } \\
\text { e }\end{array}$ & $F$ & Sig. \\
\hline \multirow[t]{3}{*}{1} & $\begin{array}{l}\text { Regress } \\
\text { ion }\end{array}$ & 3,736 & 2 & 1,868 & $\begin{array}{r}8,11 \\
6\end{array}$ &, $001^{b}$ \\
\hline & $\begin{array}{l}\text { Residua } \\
\text { I }\end{array}$ & 8,286 & 36 & 230 & & \\
\hline & Total & 12,023 & 38 & & & \\
\hline
\end{tabular}

a. Dependent Variable: Citramerek

b. Predictors: (Constant), Kualitas_produk, Gaya_hidup

\section{Pengujian Secara Parsial (Uji-t)}

Hasil pengujian secara parsial (Uji t) persamaan struktural 1 dapat dilihat pada Tabel berikut:

\section{Hasil Uji Parsial (Uji t) Model Regresi 1 \\ Coefficients $^{\mathrm{a}}$}




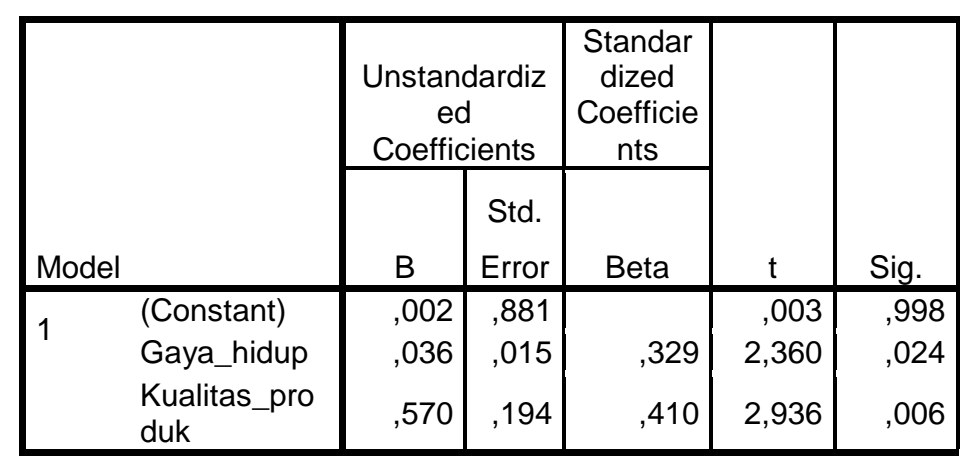

a. Dependent Variable: Citramerek

\section{Pengaruh Gaya Hidup Terhadap Citra Merek}

Berdasarkan Tabel diatas dapat diketahui bahwa nilai signifikansi $0,024<0.05$ maka dapat disimpulkan bahwa secara parsial gaya hidup berpengaruh signifikan terhadap citra merek. Artinya bahwa variabel gaya hidup secara nyata berpengaruh terhadap citra merek pada J-Co Suzuya Mall rantauprapat. Hal ini dapat menunjukkan bahwa citra merek dapat dibangun dengan meningkatkan kualitas produk.

\section{Pengaruh Kualitas Produk Terhadap Citra Merek}

Berdasarkan Tabel dapat diketahui bahwa nilai signifikansi $0,006<0.05$ maka dapat disimpulkan bahwa secara parsial kulaitas produk berpengaruh signifikan terhadap citra merek. Kualitas produk merupakan kemampuan sebuah produk atau jasa untuk memuaskan kebutuhan atau tuntutan dari pelanggan. Kualitas atau mutu suatu barang menjadi sangat penting artinya dalam dunia bisnis dengan ini kualitas dari barang yang diproduksi sangat besar pengaruhnya terhadap persepsi/citra konsumen atas produk tersebut (Nurdianto,2013)

Penelitian ini mendukung penelitian nurdiyanto dan yuniati (2013) bahwa kualitas produk berpengaruh terhadap citra merek

\section{Hasil Uji Determinasi $\left(\mathbf{R}^{2}\right)$ Model Persamaan Regresi Kedua}

Untuk melihat besarnya pengaruh pada persamaan struktural 2 yaitu pengaruh gaya hidup, kualitas produk dan citra merek terhadap keputusan pembelian terhadap kepuasan dapat dilihat pada Tabel berikut:

\section{Hasil Analisis Jalur R-Square Regresi 1}

Model Summary ${ }^{b}$

\begin{tabular}{|l|r|r|r|r|}
\hline Model & $\mathrm{R}$ & $\begin{array}{c}\mathrm{R} \\
\text { Square }\end{array}$ & $\begin{array}{c}\text { Adjusted R } \\
\text { Square }\end{array}$ & $\begin{array}{c}\text { Std. Error of the } \\
\text { Estimate }\end{array}$ \\
\hline 1 &, 550 &, 302 &, 251 &, 48695 \\
\hline
\end{tabular}
a. Predictors: (Constant), Citra_merek, Kualias_produk, Gaya_hidup
b. Dependent Variable: Keputusapembelian 
Berdasarkan Tabel diatas nilai koefisien determinasi (Adjusted $R$ Square) adalah sebesar 0,251 atau $25,1 \%$. Koefisien artinya pengaruh gaya hidup dan kualitas produk terhadap citra merek sebesar $25,1 \%$, sedangkan sisanya sebesar 74,9\% dipengaruhi oleh faktor-faktor lain.

\section{Pengujian Secara Serempak (Uji F)}

Uji F dilakukan untuk mengetahui apakah semua variabel independen yang dimasukkan ke dalam model memiliki pengaruh secara bersama-sama terhadap variabel dependen. Berikut ini merupakan hasil pengujian hipotesis secara serempak.

\section{ANOVA $^{\mathrm{a}}$ \\ Hasil Uji Simultan (Uji F) Model Regresi 2}

\section{ANOVA $^{a}$}

\begin{tabular}{|l|r|r|r|r|r|}
\hline Model & \multicolumn{1}{|c|}{$\begin{array}{c}\text { Sum of } \\
\text { Squares }\end{array}$} & df & $\begin{array}{c}\text { Mean } \\
\text { Square }\end{array}$ & F & Sig. \\
\hline${ }_{1}$ Regression & 4,212 & 3 & 1,404 & 5,921 &, $002^{\mathrm{b}}$ \\
Residual & 9,722 & 41 &, 237 & & \\
Total & 13,934 & 44 & & & \\
\hline
\end{tabular}

a. Dependent Variable: Keputusapembelian

b. Predictors: (Constant), Citra_merek, Kualias_produk,

Gaya_hidup

\section{Pengujian Secara Parsial (Uji t)}

Pengujian secara parsial menguji pengaruh variabel independen yaitu gaya hidup, kualitas produk dan citra merek terhadap keputusan pembelian. Hasil pengujian secara parsial (Uji-t) persamaan struktural 2 dapat dilihat pada Tabel berikut:

\begin{tabular}{|c|c|c|c|c|c|c|}
\hline \multirow[b]{2}{*}{ Model } & & \multicolumn{2}{|c|}{$\begin{array}{l}\text { Unstandardi } \\
\text { zed } \\
\text { Coefficients }\end{array}$} & \multirow{2}{*}{$\begin{array}{c}\begin{array}{c}\text { Standar } \\
\text { dized } \\
\text { Coefficie } \\
\text { nts }\end{array} \\
\text { Beta } \\
\end{array}$} & \multirow[b]{2}{*}{$t$} & \multirow[b]{2}{*}{ Sig. } \\
\hline & & $\mathrm{B}$ & $\begin{array}{l}\text { Std. } \\
\text { Error }\end{array}$ & & & \\
\hline \multirow[t]{4}{*}{1} & (Constant) & \begin{tabular}{r|}
2,64 \\
7
\end{tabular} & ,661 & & 4,006 &, 000 \\
\hline & Gaya_hidup & , 182 & ,097 & ,249 & 1,875 & ,058 \\
\hline & Kualias_produk & ,169 & ,076 & ,291 & 2,223 & ,032 \\
\hline & Citra_merek & ,210 &, 084 & ,330 & 2,481 &, 017 \\
\hline
\end{tabular}




\section{Pengaruh Gaya Hidup Terhadap Keputusan pembelian}

Berdasarkan Tabel diatas dapat diketahui bahwa nilai signifikansi $0,058<0.05$ maka dapat disimpulkan bahwa secara parsial gaya hidup berpengaruh signifikan terhadap keputusan pembelian. Hal ini menunjukkan bahwa semakin tinggi tingkat gaya hidup seseorang mencerminkan semakin tinggi kelass sosial mereka. Hal ini dapat dilihat dari banyaknya keinginan pelanggan untuk mengkonsumsi barang -barang mewah, J-Co misalnya merupakan coffe shop yang dianggap massyarakat dapat merubah status sosial mereka ketika mengkonsumsinya.

Penelitian ini mendukung penelitian Prastiwi (2016) bahwa gaya hidup berpengaruh terhadap keputusan pembelian .

2. Pengaruh Kualitas Produk Terhadap Keputusan Pembelian

Berdasarkan Tabel diatas dapat diketahui bahwa nilai signifikansi $0,032<0.05$ maka dapat disimpulkan bahwa secara parsial kualitas produk berpengaruh signifikan terhadap keputusan pembelian. Hal ini menunjukkan bahwa semakin baik kualitas produk maka akan semakin banyak pelanggan yang tertarik untuk melakukan pembelian.

3. Pengaruh Citra Merek Terhadap Keputusan Pembelian

Berdasarkan Tabel diatas dapat diketahui bahwa nilai signifikansi $0,017<0.05$ maka dapat disimpulkan bahwa secara parsial citra merek berpengaruh signifikan terhadap keputusan pembelian. Apabila suatu produk memiliki brand image positif dan diyakini oleh konsumen dapat memenuhi kebutuhan dan keinginannya, maka dengan sendirinya akan menumbuhkan keputusan pembelian konsumen akan produk yang ditawarkan.

Hasil penelitian ini mendukung penelitian Muwarah (2013) bahwa brand image mempunyai pengrauh yang signifikan terhadap keputusan pembelian.

\section{Pengaruh Gaya Hidup terhadap keputusan Pembelian Melalui Citra Merek}

Hasil penelitian menunjukkan bahwa Gaya hidup tidak berpengaruh siginifikan terhadap keputusan pembelian melalui citra merek. Hal ini berrati bahwa citra merek sebagai variabel intervening tidak mampu memediasi pengaruh gaya hidup terhadap keputusan pembelian.

5. Pengaruh Kualitas produk terhadap keputusan pembelian melalui citra merek

Hasil penelitian menunjukkan bahwa kualitas produk berpengaruh siginifikan terhadap keputusan pembelian melalui citra merek. Hal ini berati bahwa citra merek sebagai variabel intervening t mampu memediasi pengaruh kualitas produk terhadap keputusan pembelian. Penelitian ini mendukung penelitian Parasayu dan widayanto bahwa kualitas produk berpengaruh siginifikan terhadap keputusan pembelian melalui citra merek.

\section{E.KESIMPULAN DAN SARAN \\ Kesimpulan}

Berdasarkan hasil analisis dan pembahasan, maka dapat disimpulkan sebagai berikut: 


\section{Jurnal Ecobisma Vol 5 No. 1 Juni 2018}

1. Secara parsial gaya hidup berpengaruh signifikan terhadap citra merek pada J-Co Suzuya Mall Rantauprapat

2. Secara parsial kualitas produk berpengaruh signifikan terhadap citra merek pada J-Co Suzuya Mall Rantauprapat

3. Secara parsial gaya hidup berpengaruh signifikan terhadap keputusan pembelian pada J-Co Suzuya Mall Rantauprapat

4. Secara parsial kualitas produk berpengaruh signifikan terhadap keputusan pembelian pada JCo Suzuya Mall Rantauprapat

5. Gaya hidup tidak berpengaruh signifikan terhadap keputusan pembelian melalui citra merek pada J-Co Suzuya Mall Rantauprapat

6. Kualitas hidup berpengaruh signifikan terhadap keputusan pembelian melalui citra merek pada J-Co Suzuya Mall Rantauprapat

\section{DAFTAR PUSTAKA}

Aaker, D. (2014). Building Strong Brands. (A. Baderi, Trans.) Jakarta: Bumi Aksara.

Kotler, Philip. 2005. Manajemen Pemasaran. Jilid 1 dan 2. Jakarta : PT Indek

Kotler, Philip. Keller, K Lane, 2009. Manajemen Pemasaran. Edisi 13. Penerbit Erlangga, Jakarta.

Kotler, Philip dan Kevin Lane Keller, 2008. Manajemen Pemasaran, Jilid 1, Penerbit Erlangga. Jakarta.

Napitupulu, Petrus. 2018. Pengaruh Citra Merek, Harga Dan Gaya Hidup Terhadap Loyalitas Pelanggan Pada Starbuck Focal Point Medan. Skripsi Universitas Sumatera Utara Fakultas Ekonomi dan Bisnis

Sudarmono dan Kholidin. 2015. Upaya Meningkatkan Kinerja Penjualan Coffee Shop Melalui Analisis Variabel Store Atmosphere, Citra Merek, Preferensi Merek Coffee Shop Di Media Sosial Dan Promosi (Temuan Pada J.Co Paragon Mall, Semarang). Jurnal Manajemen Bisnis Indonesia Vol.2 No.3

Schiffman, Leon G., Kanuk, Leslie Lazar. 2008. Perilaku Konsumen. Edisi Ketujuh. Alih Bahasa: Zoelkifli Kasip. Jakarta: Indeks. 